\title{
Grip Benzeri Şikayetler ile Hastaneye Yatırılan Çocuklarda İnfluenza Sıklığı, İnfluenza Tipleri ve İnfluenza Aşısı Kullanımı
}

\section{Frequency of Influenza, Influenza Types and Influenza Vaccine Use in Hospitalized Children with Influenza-Like Symptoms}

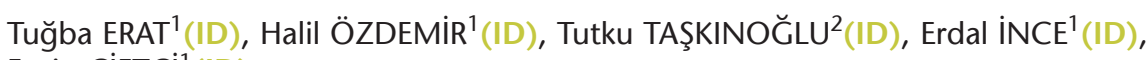 \\ Ergin ÇiFTÇili(ID)! \\ ${ }^{1}$ Ankara Üniversitesi Tıp Fakültesi, Çocuk Enfeksiyon Hastalıkları Bilim Dalı, Ankara. \\ ${ }^{1}$ Ankara University Faculty of Medicine, Department of Pediatric Infectious Diseases, Ankara, Turkey. \\ 2 Düzen Laboratuvarlar Grubu, Mikrobiyoloji Laboratuvarı, Ankara. \\ 2 Duzen Laboratories Group, Microbiology Laboratory, Ankara, Turkey.
}

\section{* Bu çalışmada, "Global Influenza Hastane Sürveyans Ağı Projesi 2016-2017, Türkiye" başlıkı proje kapsamında gerçekleştiril- miş olup 11. Ulusal Çocuk Enfeksiyon Hastalıkları Kongresi (4-8 Nisan 2018, Antalya)’nde sözlü bildiri olarak sunulmuştur.} Makale Atıfı: Erat T, Özdemir H, Taşkınoğlu T, Ince E, Çiftçi E. Grip benzeri şikayetler ile hastaneye yatırılan çocuklarda
influenza sıklığı, influenza tipleri ve influenza aşısı kullanımı. Mikrobiyol Bul 2020;54(2):318-325.

ÖZ

İnfluenza (grip), influenza virüsünün neden olduğu bir solunum yolu hastalığı olup çocuklarda morbidite ve mortalitenin önemli bir nedenidir. Her yıl epideminin yaygınlığını, gelişebilecek pandemiyi, hastaneye yatışı, mortalite oranını ve sonraki yılın aşı içeriğini virüs alt tipleri belirlemektedir. Küresel İnfluenza Hastane Sürveyans Ağı (Global Influenza Hospital Surveillance Network ${ }^{\circledR}$ ), birçok ülkeden üçüncü basamak hastanelerin katıldığı ve influenza virüs enfeksiyonunun epidemiyolojik olarak takip edildiği uluslararası sürveyansın yapıldığı bir kurumdur. Bu kurumun 2016-2017 sezonunda düzenlediği çalışmaya ülkemizden 6 merkez katılmıştır. Bu çalışmada, 2016-2017 sonbahar-kış döneminde hastanemize influenza benzeri belirtiler ile başvuran ve hastaneye yatışı gereken hastalarda influenza sıklığının, virüs tiplerinin, klinik özelliklerinin ve aşılanma oranlarının belirlenmesi amaçlanmıştır. İnfluenza benzeri belirtiler ile Çocuk Enfeksiyon Hastalıkları Kliniğine yatırılan ve çalışmaya uygun olan hastalar belirlenmiş, ailelerinden aydınlatılmış onam alınmıştır. Yatışından itibaren ilk 24-48 saat içerisinde 217 çocuk hasta taramadan geçirilmiş ve 184 'ü çalışmaya dahil edilerek nazofarengeal sürüntü örnekleri alınmıştır. Gerçek zamanlı ters transkriptaz polimeraz zincir reaksiyonu ile influenza virüsü saptanarak virüs tespit edilen örneklerde alt tiplendirme yapılmıştır. İnfluenza pozitif hastaların \%83.3'ünün 5 yaş altında olduğu belirlenmiştir. Toplam 30 (\%16.3) hasta influenza pozitif bulunmuş ve izolatların \%70'i influenza A (H3N2), \%30'u influenza B (Yamagata) olarak belirlenmiştir. İnfluenza A (H1N1) veya influenza B (Victoria) saptanmamıştır. İnfluenza pozitifliği saptanan olguların \%30'unda altta yatan hastalık tespit edilmiş ve nöromusküler, kardiyovasküler hastalıklar ve astım en sık görülen altta yatan hastalık olarak belirlenmiştir. İnfluenza pozitif olguların sigara maruziyeti \%86.6 olarak bulunmuştur. İnfluenza benzeri bulguları olan hastaların \%28.2'sine ampirik antiviral tedavi başlanmıştır. Çalışmaya dahil edilen hastalarda influenza aşılanma oranı çok düşük (\%1.6) bulunurken, aşılananların hiçbirisinde influenza virüsü saptanmamıştır. İnfluenza pozitifliği olan 3 hasta pediatrik yoğun bakıma yatırılmış ve 2'sinin mekanik ventilatör gereksinimi olmuştur. 
Hiçbir hastada ekstrakorporeal membran oksijenizasyonu gereksinimi veya ölüm izlenmemiştir. Sonuçlarımız, pandemiye yol açabilen influenzanın sürveyansının önemini vurgulamakta ve özellikle çocuklar gibi, morbidite ve mortalite açısından riskli grupların influenza aşılanma oranlarının artırılması gerekmektedir.

Anahtar kelimeler: Çocuk; grip; influenza aşısı; influenza virüsü; sürveyans.

\section{ABSTRACT}

Influenza is an important cause of respiratory illness in children and is still an important cause of morbidity and mortality in children. The influenza virus subtypes determine the prevalence of the epidemic and pandemic influenza, the hospitalization and mortality rates in children each year. Surveillance of the circulation of different influenza virus strains is important in ensuring a good strain con-cordance for the composition of the annual influenza vaccine. The Global Influenza Hospital Surveillance Network ${ }^{\circledR}$ (GIHSN) is an international institution in which tertiary hospitals from many countries participate and where epidemiological surveillance of influenza disease is conducted. Six centers from Turkey participated in the study organized by GIHSN during the influenza season 2016-2017. The aim of this study was to demonstrate the frequency of influenza, virus types, clinical characteristics and vaccination rates in children admitted to our hospital with influenza-like symptoms in the influenza season 2016-2017. Informed consents were obtained from patients. 217 pediatric patients were screened with in the $24^{\text {th }}$ and $48^{\text {th }}$ hours of the hospitalization. Then a nasal/nasopharyngeal swab were collected from 184 patients who met the inclusion criteria. Real-time reverse-transcription polymerase chain reaction (rRT-PCR) was used to obtain laboratory results. Influenza virus, influenza virus subtypes were studied by rRT-PCR. The $83.3 \%$ of the patients with positive influenza was under 5 years of age. The rate of influenza positivity was $16.3 \%$ ( $n=30$ patients). Influenza A (H3N2) was the predominant strain in children. The $70 \%$ of isolates were influenza $A(\mathrm{H} 3 \mathrm{~N} 2)$ and the $30 \%$ were influenza $B$ (Yamagata). There were no case of influenza A (H1N1) or influenza B (Victoria). In $30 \%$ of cases with influenza positivity, there was an underlying disease. The most prevalent of them were neuromuscular disease followed by cardiovascular disease and asthma. Tobacco exposure was $86.6 \%$ in influenza positive cases. The empirical oseltamivir prescription rate was $28.2 \%$. The vaccination rate of the influenza vaccine was very low (1.6\%). The out of 3 patients with influenza positivity were admitted to pediatric intensive care unit, and 2 of them required mechanical ventilation. None of these patients required extracorpereal membrane oxygenation and did not die. Our results highlight the importance of surveillance for influenza and in particular, influenza vaccination rates of groups with risk for morbidity and mortality, such as children, need to be increased.

Keywords: Child; influenza; influenza vaccine; influenza virus; surveillance.

\section{Giriş}

İnfluenza virüsü, insandan insana damlacık veya temas yolu ile bulaşarak mevsimsel yaygın epidemilere yol açar. Toplum kaynaklı salgınlarda en yüksek insidans okul çağı çocuklarında olmakla birlikte hastaneye en sık başvuru iki yaş altı çocuklar ve 65 yaş üzerindeki kişilerde olmaktadır. İnfluenza virüs enfeksiyonunun; akut otitis media, bronşiyolit, pnömoni ve sinüzit gibi komplikasyonlarının yanında, febril konvülsiyon, ensefalit ve miyokardit gibi daha ciddi tablolara da neden olduğu bilinmektedir. Hastaneye yatışı olan hastaların birçoğunun altta yatan hastalığı bulunmadığı bilinmektedir. Ancak, hemodinamik açıdan stabil olmayan kardiyak hastalığı, nörolojik hastalığı, nörogelişimsel geriliği olan hastalık ile orak hücre anemisi gibi hemoglobinopatisi olan hastalar için artmış risk olduğu bilinmektedir. Influenza sezonu boyunca influenza ve influenzaya ikincil komplikasyonlar için antimikrobiyal ilaç kullanımında \%30'a kadar artış görülmektedir, çoğu zaman ise bu antimikrobiyal ilaçların gereksiz reçete edildiği de bilinmektedir ${ }^{1-3}$. 
İfluenzanın mevsimsel ciddi morbidite ve mortaliteye neden olması sürveyans sistemlerinin önemini artırmışıı. İnfluenzanın sağlık sistemi üzerine oluşturduğu güncel yükü bilmek, pandemilere hazırıklı olmak, bir sonraki mevsim için aşı içeriğini belirlemek ve aşılanma oranları hakkında bilgi elde etmek bunlardan bazılarıdır. Ülkemizde Ulusal Sentinel Sürveyans Ağı, Küresel Influenza Hastane Sürveyans Ağı (Global Influenza Hospital Surveillance Network $\left.^{\circledR}\right)\left(\right.$ KiHSA) ile influenza hastalığının epidemiyolojik verilerine katkı sağlamaktadır ${ }^{4-6}$.

Bu çalışmada, son altı aydır Ankara ilinde ikamet eden, 2016-2017 ylı influenza mevsiminde hastanemize influenza benzeri belirtiler ile başvuran ve hastaneye yatışı gereken çocuk hastalar incelenerek influenza sıkığının, virüs tiplerinin, klinik özelliklerinin ve aşılanma oranlarının belirlenmesi amaçlanmıştır.

\section{GEREÇ ve YÖNTEM}

Bu çalışmada, Hacettepe Üniversitesi Girişimsel Olmayan Klinik Araştırmalar Etik Kurul onayı ile gerçekleştirilen "Global İnfluenza Hastane Sürveyans Ağı Projesi 2016-2017, Türkiye" başlıklı projenin bir bölümü sunuldu (Tarih: 17.01.2017 ve Karar no: GO 16/793-06).

KiHSA-Türkiye Projesi, 13 Aralık 2016 (51. hafta)-15 Nisan 2017 (16. hafta) tarihleri arasında KiHSA'nın uluslararası koordinasyon merkezince yürütülen ileriye dönük bir epidemiyolojik çalışmadır. Bu projeye, Türkiye'den 2815 yatak kapasiteli erişkin ve çocuklara hizmet veren üçüncü basamak altı merkez katıldı.

Çalışma protokolüne göre son 6 aydır Ankara'da ikamet eden, 18 yaşından küçük, influenza benzeri belirtilerin son yedi gün içinde başladığı ve son bir ay içinde benzer bulgular nedeniyle hastaneye yatışı olmayan ve bakımevinde kalmayan hastalardan aydınlatılmış onam alınarak çalışmaya uygun hastalar seçildi. İnfluenza sezonu her yılın 40. haftası ile bir sonraki yılın 20. haftası arasındadır. Çalışma, KiHSA kapsamında Kuzey Yarımküre için influenza olgularının daha sık görüldüğü 13 Aralık 2016 (51. hafta) ile 15 Nisan 2017 (16. hafta) tarihleri arasında yapıldı. Çocuk acil servis, çocuk enfeksiyon servisi ve çocuk yoğun bakım ünitesine son 24-48 saat içinde yapılan tüm yatışlar sistematik olarak tarandı. Hastalar, önceden belirlenen Uluslararası Hastalık Sınıflandırması-10 (ICD-10) kodlarına göre uygunluk yönünden değerlendirildi.

Beş yaş ve üzerinde olan hastalar; son 7 gün içinde ateş, baş ağrısı, miyalji ve kırgınlık şeklinde var olan sistemik belirtilerden en az biri ile öksürük, boğaz ağrısı ve nefes darlığı şeklinde var olan solunum belirtilerinden en az birinin olması durumunda çalışmaya alınırken, 5 yaş altındaki hastalar yatış gerektiren durumlar 7 gün içerisinde ortaya çıkmış ise çalışmaya alındı. Çalışmaya dahil edilen hastaların yaşı, cinsiyeti, başvuru belirtileri, altta yatan hastalıkları, sigara maruziyeti ve influenza aşııı durumları sorgulandı.

Çalışmaya alınan hastalardan nazofarengeal sürüntü örnekleri protokole göre toplandı. "Medical Wire M40-A Compliant Sigma-VirocultTM Viral Collection and Transport System" ve "Sigma-SwabTM with Virocult" sistemleri örnek toplanması için kullanıldı. Tüm örnekler kurye ile günlük olarak laboratuvara ulaştııılı ve $-20^{\circ} \mathrm{C}^{\prime}$ de saklandı. Nükleik asit izolasyonu için EZ1 virüs mini kit V2.0 kullanıldı. Solunum patojenlerinin tanısında influenza virüslerini 
saptayan revers transkriptaz polimeraz zincir reaksiyonu (RT-PCR) (Flu/hRSV, FTD, Malta) kiti ve amplikonların saptanmasında RotorGene (Qiagen, Almanya) cihazı kullanıldı. İnfluenza alt tiplerinin saptanması için, "Centers for Disease Control and Prevention (CDC)" protokolüne göre $C D C^{\prime}$ nin önerileri doğrultusunda primer ve problar ile gerçek zamanlı RT-PCR (rRT-PCR) yöntemi uygulandı ${ }^{6,7}$.

\section{İstatistiksel Analiz}

İstatistiksel analiz, "SPSS Statistical Package versiyon 16.0" kullanılarak yapıldı. Çalışmada tanımlayıcı istatistiksel yöntem kullanıldı. Parametrelerin normal dağılımı KolmogorovSmirnov testi ile kontrol edildi, ortalamalar ve ilişkili standart sapmalar normal dağılımlı değişkenler için sağlandı. Kesikli verilerde ise yüzde değerleri verildi. Normal dağılıma sahip olmayan sürekli veriler minimum, maksimum ve ortanca olarak verildi.

\section{BULGULAR}

2016-2017 sonbahar-kış döneminde influenza benzeri belirtiler ile toplam 217 çocuk hasta yatırılarak incelemeye alınmıştır. Dahil olma kriterlerini karşılayan ve çalışmaya katılmayı kabul eden toplam 184 hasta çalışmaya alınmıştır. Hastaların ortanca yaşı 8 ay (1 ay-17 yıl 8 ay) olarak belirlenmiş ve 167 (\%90.8) hastanın 5 yaş altında olduğu saptanmıştır. Hastaların 99 (\%53.8)'u erkek olarak tespit edilmiştir. Hastaneye yatırılan hastaların \%33.6'sının doğum kilosu 2500 gramın altında olup prematürite oranı \%20.7 olarak belirlenmiştir. Beş yaş altı hastaların \%36.6'sı 6 aydan kısa süre anne sütü almıştır. Toplam 30 (\%16.3) hastada influenza virüs pozitifliği saptanmıştır. Bu hastalardan 25 (\%83.3)'i 5 yaş altında bulunmuştur. İzole edilen influenza izolatlarının 21 (\%70)'i influenza A (H3N2), 9 (\%30)'u influenza B (Yamagata) olarak belirlenmiş ve izolatlar arasında influenza A (H1N1) ve influenza B (Victoria) saptanmamıştır (Tablo I).

\begin{tabular}{|c|c|c|c|}
\hline & $<5$ yaş $\mathrm{n}(\%)$ & $\geq 5$ yaş $\mathrm{n}(\%)$ & Toplam n (\%) \\
\hline & $167(\% 90.8)$ & $17(\% 9.2)$ & $184(\% 100)$ \\
\hline Ortanca yaş (ay) & $5(1-59)$ & $98(64-212)$ & $8(1-212)$ \\
\hline Erkek cinsiyet, n (\%) & $93(\% 55.6)$ & $6(\% 35.2)$ & $99(\% 53.8)$ \\
\hline \multicolumn{4}{|c|}{ RT-PCR sonuçları, n (\%) } \\
\hline İnfluenza negatif & $142(\% 85)$ & $12(\% 70.5)$ & $154(\% 83.7)$ \\
\hline İnfluenza pozitif & $25(\% 15)$ & $5(\% 29.5)$ & $30(\% 16.3)$ \\
\hline \multicolumn{4}{|l|}{ İnfluenza alt tipleri } \\
\hline İnfluenza A & $18(\% 72)$ & $3(\% 60)$ & $21(\% 70)$ \\
\hline H1N1 & $0(\% 0)$ & $0(\% 0)$ & $0(\% 0)$ \\
\hline $\mathrm{H} 3 \mathrm{~N} 2$ & $18(\% 100)$ & $3(\% 100)$ & $21(\% 100)$ \\
\hline İnfluenza B & $7(\% 28)$ & $2(\% 40)$ & $9(\% 30)$ \\
\hline Yamagata & $7(\% 100)$ & $2(\% 100)$ & $9(\% 100)$ \\
\hline Victoria & $0(\% 0)$ & $0(\% 0)$ & $0(\% 0)$ \\
\hline
\end{tabular}




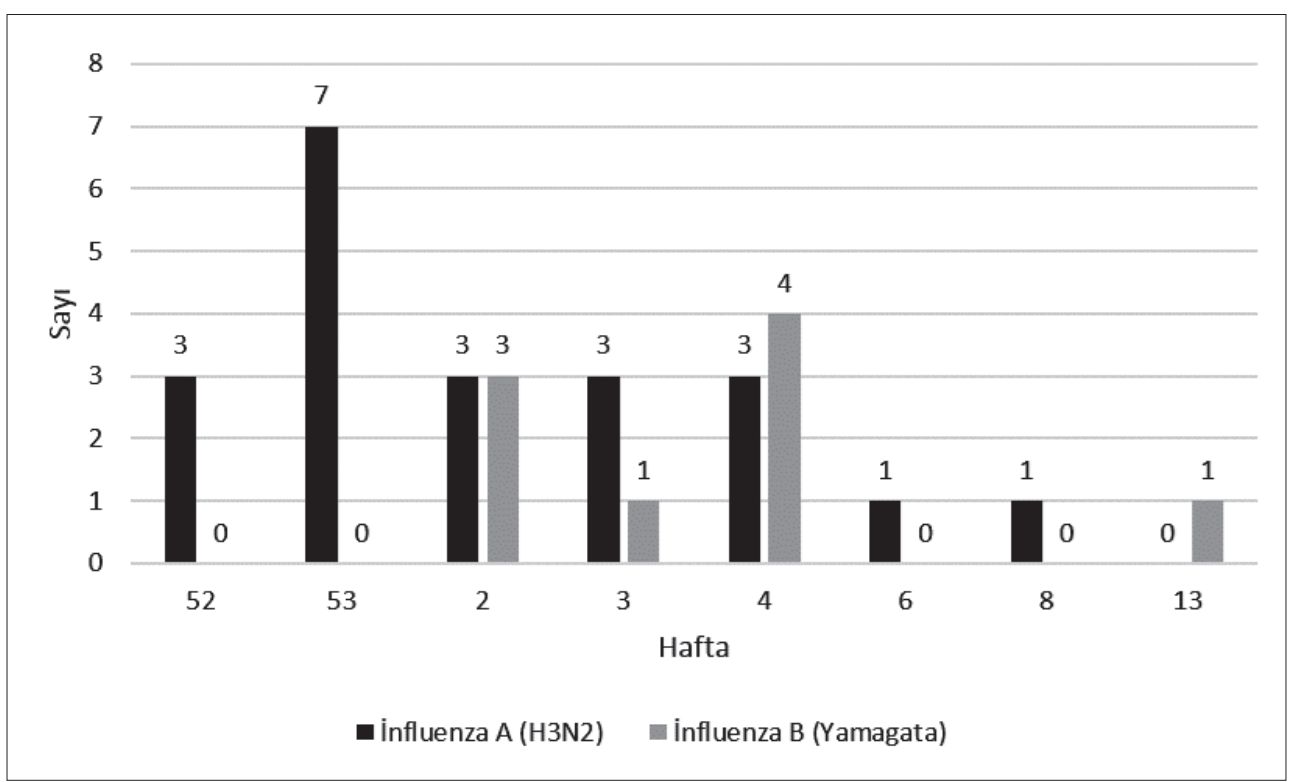

Şekil 1. Influenza alttiplerinin haftalara göre dağılımı (2016-2017 influenza sezonu).

Illk influenza olguları 52. haftada, son olgu ise 13. haftada görülmüştür. İnfluenza virüsünün alt tiplerine göre görüldüğü haftalara bakıldığında ilk dönemde influenza A (H3N2)'nin daha ön planda, influenza B'nin ise 2017 yılının ilk 4 haftasında daha sık olduğu görülmektedir (Şekil 1). Alt tiplerin yaşlara göre dağılımına bakıldığında istatistiksel olarak anlamlı fark olmamakla birlikte, influenza B 5 yaş üstünde daha sık tespit edilmiştir.

İnfluenza pozitifliği saptanan hastaların \%70'inin daha önceden sağlıklı çocuklar olduğu görülmüştür. Altta yatan hastalık oranı \%30 olup, en sık görülen hastalıklar nöromusküler, kardiyovasküler ve astım olarak belirlenmiştir. İnfluenza pozitif hastalarda sigara maruziyeti (ebeveyni kullanan ve kendisi sigara kullanan) sorgulandığında oran \%86.6 olarak saptanmıştır.

Üç (\%10) hastada yoğun bakım ihtiyacı olmuş ve 2 hasta mekanik ventilatöre bağlı olarak izlenmiştir. Bu hastaların 2'sinde influenza A (H3N2) ve 1'inde influenza B (Yamagata) pozitif saptanmıştır. İnfluenza benzeri belirtileri olan hastaların 52 (\%28.2)'sinde ampirik oseltamivir başlanmıştır. Bu sezonda yalnız 3 (\%1.6) hastaya influenza aşısı yapılmıştır. Aşılı hastaların hiçbirisinde influenza tespit edilmemiştir. Hastaların hiçbirinde organ yetmezliği veya ekstrakorporeal membran oksijenizasyonu ihtiyacı olmamış ve hastaların hiçbiri kaybedilmemiştir.

\section{TARTIŞMA}

Bu çalışma, hastanemize influenza benzeri belirtiler ile başvuran ve hastaneye yatış gerektiren ciddi hastalığı olan çocuk hastalarda influenza sıklığının, influenza virüs tiplerinin, hastalığın klinik özelliklerinin ve influenza ile aşılanma oranlarının belirlenmesi amacıyla 
yapılmıştır. KiHSA verilerinde influenzanın Kuzey Yarımkürede 2016/49. hafta ile 2017/2. hafta arasında sık görüldüğü ve pik insidansı bu dönemde yaptığı belirtilmiştir ${ }^{8}$. Çalışmamızda da influenza pozitiflikleri 2016/52. hafta ile 2017/16. hafta arasında görülmüş, asıl yoğunluk 52. hafta ile 4. hafta arasında saptanmıştır. Pik insidansı benzer şekilde bu dönemde yapmışır. Romanya'nın 2016-2017 influenza verilerinde, influenzanın görülmeye başlaması ve pik yapma tarihi çalışmamı ile benzerdir 9 .

Influenza A (H3N2), Kuzey Yarımkürede yaygın alt tip (\%70.3) olarak sezon boyunca görülmüştür. KiHSA-Türkiye ve çalışma verilerimizde Tablo I'de de görüldüğü gibi influenza A (H3N2) baskın alt tip olarak \%70 oranında saptanmıştır. 2015-2016 influenza verileri ile karşılaştııılığında influenza A (H1N1) alt tipinin görülmemesi dikkat çekicidir. Ülkemiz için, 2016-2017 ile 2015-2016 sezonunda influenza B'nin görülme sıklığı sırasıyla \%20.8 ve \%7.8'dir. İnfluenza B görülme sıklığı da artmıştır. 2016-2017 sezonu Avrupa CDC verilerine göre diğer Avrupa ülkeleri ile karşılaştıııldığında, influenza $B$ görülme sıklığı ülkemizde fazladır (\%20.8 ve \%12.8) ${ }^{10}$. Influenza B alt tipi görülme sıklığı ise bölgelere göre değişkendir. Türkiye, Tunus, Çekya ve Kanada gibi bazı ülkelerde Yamagata alt tipi sık görülürken, Romanya, Rusya ve Hindistan'da ise Victoria alt tipi sık görülmüştür. Influenza B daha sık 5-17 yaş arasında ve ikinci haftadan sonra görülmüştür. Çalışmamızda da beş yaş üstü grupta daha sık olup 2.-4. haftalarda pik yapmıştır (Şekil 1) 8,9. $^{8,9}$.

Influenza ilişkili ölüm, altta yatan hastalığı olan çocuklarda görüldüğü gibi tamamen sağlıklı çocuklarda da bildirilmiştir ${ }^{11,12}$. 2016-2017 sezonu CDC raporuna göre, hastaneye yatan pediatrik olgular incelendiğinde 0-4 yaş ve 5-17 yaş aralığında sırasıyla yüz binde 41.4 ve 15.7 olarak belirtilmiş ve 110 çocuk hastanın öldüğü bildirilmiştir ${ }^{13}$. Altta yatan hastalıklara bakıldığında ise, CDC'nin 2017 verileri ile benzerlik görülmektedir ${ }^{14}$. Influenza nedeniyle hastaneye yatan hastalarda sigara maruziyetinin $\% 86.6$ olması dikkat çekicidir. Daha önce yapılan çalısmalarda da influenza ile sigara maruziyetinin hastaneye yatış ve akut solunum yetmezliği ile ilişkili olduğu bildirilmiştir ${ }^{15-17}$.

2016-2017 sonbahar kış döneminde çalışmaya katılan çocuk hastalarda influenza aşılanma oranı \%1.6 olup çok düşüktür. Bu nedenle aşı etkinliği değerlendirilememiştir. KiHSA verilerinde 2016-2017 yılı aşı etkinliği sadece altı bölgede çalışılabilmiştir ve influenza aşı etkinliği \%27.2 bulunmuştur. Bu oran 2-4 yaş aralığında ve 85 yaş üstünde özellikle influenza B için en yüksek oranda saptanmıştır ${ }^{8}$. Chiu ve arkadaşları ${ }^{18}, 6$ ay-17 yaş arasında Hong Kong'da 2016-2017 influenza sezonunda yaygın alt tip olan influenza A (H3N2)'ye karşı aşı etkinliğini değerlendirmişler ve aşılanma sonrası ilk üç ay içerisinde etkinliğinin en yüksek \%52.8 olduğunu açıklamışlardır. Luo ve arkadaşları ${ }^{19}$ ardışık iki influenza sezonunda aşı etkinliğini değerlendirdikleri çalışmalarında, ağırıılı alt tip olan influenza A (H3N2) ile birlikte, influenza A (H1N1), influenza B alt tiplerine karşı 6-72 ay arası çocuklarda aşı etkinliğini tüm influenza tiplerine karşı \%58, 36-72 ay arasındaki çocuklarda ise \%68 olarak bildirmişlerdir. Etkinlik influenza A (H3N2) alt tipine karşı daha fazladır. Aşı etkinliğini 36-72 aylık çocuklarda daha etkili bulmuşlardır. Türkiye'deki beş yaş altı influenza aşılanma oranları 2013-2014, 2014-2015, 2015-2016 ve 2016-2017 
sezonlarında sırasıyla, $\% 0.3, \% 0.8, \% 2.1$ ve $\% 1.3^{\prime}$ tür $^{20}$. Bu oranların çok düşük olması Türkiye'de çocuklarda aşı etkinliğinin değerlendirilmesini zorlaştırmıştır. Ülkemizde, Sosyal Güvenlik Kurumu kapsamında 65 yaş üstü kişilere, altta yatan hastalığı olanlara influenza aşıı ücretsiz olarak yapılmaktadır. Ülkemizde çok düşük olan aşılanma oranlarının artırılması için yeni girişimler yapılmalıdır.

Sonuç olarak, çalısmamızda 2016-2017 sezonunda influenza benzeri belirtileri nedeni ile yatırılan ve influenza izole edilen çocuk hastalarda en yaygın görülen alt tipin influenza A (H3N2) olduğu ve influenza B (Yamagata) alt tipinin ikinci sıklıkla görüldüğü tespit edilmiştir. İnfluenza A (H1N1) alt tipi ise hiç saptanmamıştır. Sonuçlarımız genel olarak KiHSA verileri ile benzer olup dikkat çekici diğer bir bulgu influenza aşılanma oranının çok düşük olmasıdır.

\section{ÇIKAR ÇATIŞMASI}

Yazarlar bu makale ile ilgili herhangi bir çıkar çatışması bildirmemişlerdir.

\section{KAYNAKLAR}

1. American Academy of Pediatrics. Influenza, pp: 476-90. In: Kimberlin DW, Brandy MT, Jackson MA, Long SS (eds), Red Book: 2018 Report of the Committee on Infectious Diseases. 2018, 31 ${ }^{\text {st }}$ ed. Park Blvd. Itasca.

2. Fraaij PL, Heikkinen T. Seasonal influenza: the burden of disease in children. Vaccine 2011; 29(43): $7524-8$.

3. Low D. Reducing antibiotic use in influenza: challenges and rewards. Clin Microbiol Infect 2008; 14(4): 298-306.

4. Smith PF, Hadler JL, Stanbury M, Rolfs RT, Hopkins RS; CSTE Surveillance Strategy Group. "Blueprint version 2.0": updating public health surveillance for the $21^{\text {st }}$ century. J Public Health Manag Pract 2013; 19(3): 231-9.

5. Akçay Ciblak M, Kanturvardar Tütenyurd M, Asar S, Tulunoğlu M, Fındıkçı N, Badur S. Reference laboratory, Istanbul Faculty of Medicine, Turkey. Mikrobiyol Bul 2012; 46(4): 575-93.

6. Özışık L, Durusu Tanrı̈ver M, Çıblak Akçay M, Yuntçu K, Ünal S, Badur S, et al. Mortality related factors in patients requiring hospitalization for influenza like illness. Mikrobiyol Bul 2017; 51(1): 20-31.

7. World Health Organization. CDC protocol of real-time RT-PCR for influenza A(H1N1). http://www.who.int/ csr/resources/publications/swineflu/realtimeptpcr/en/.

8. Baselga-Moreno V, Trushakova S, McNeil S, Sominina A, Nunes MC, Draganescu A, et al. Influenza epidemiology and influenza vaccine effectiveness during the 2016-2017 season in the Global Influenza Hospital Surveillance Network (GIHSN). BMC Public Health 2019; 19(1): 487.

9. Draganescu A, Sandulescu O, Florea D, Vlaicu O, Streinu-Cercel A, Otelea D, et al. The influenza season 2016/17 in Bucharest, Romania-surveillance data and clinical characteristics of patients with influenza-like illness admitted to a tertiary infectious diseases hospital. Braz J Infect Dis 2018; 22(5): 377-86.

10. European Centre for Disease Prevention and Control (ECDC). Annual epidemiological report for 2016. Stockholm: ECDC; 2018. https://ecdc.europa.eu/en/publications-data/seasonal-influenza-annual epidemiological-report-2016-17-season

11. Bustos BR, Andrade YF. Acute encephalopathy and brain death in a child with influenza A (H1N1) during the 2009 pandemic. Rev Chilena Infectol 2010; 27(5): 413-6.

12. Kendirli T, Demirkol D, Yildizdas D, Anil AB, Asilioğlu N, Karapinar B, et al. Critically ill children with pandemic influenza (H1N1) in pediatric intensive care units in Turkey. Pediatr Crit Care Med 2012; 13(1): 11-7.

13. Centers for Disease Control and Prevention. FluView 2016-2017 Data as of 2017. Available at: https://www. cdc.gov/flu/weekly/fluviewinteractive.htm 
14. Centers for Disease Control and Prevention. FluView 2016-2017 Data as of 2017. Available at: https://gis. cdc.gov/grasp/fluview/FluHospChars.html

15. Abadom TR, Smith AD, Tempia S, Madhi SA, Cohen C, Cohen AL. Risk factors associated with hospitalization for influenza-associated severe acute respiratory illness in South Africa: A case population study. Vaccine 2016; 34(46): 5649-55.

16. Marlet J, Gaudy-Graffin C, Marc D, Boennec R, Goudeau A. Factors associated with influenza vaccination failure and severe disease in a French region in 2015. PLoS One 2018; 13(4): e0195611.

17. Hong MJ, Gu BH, Madison MC, Landers C, Tung HY, Kim M, et al. Protective role of $\gamma \delta \mathrm{T}$ cells in cigarette smoke and influenza infection. Mucosal Immunol 2018; 11(3): 894-908.

18. Chiu SS, Kwan MYW, Feng S, Wong JSC, Leung CW, Chan ELY, et al. Influenza vaccine effectiveness against influenza A (H3N2) hospitalizations in children in Hong Kong in a prolonged season, 2016/2017. J Infect Dis 2018; 217(9): 1365-71.

19. Luo SY, Zhu JL, Lyu MZ, Hu YQ, Cheng H, Zhang GM, et al. Evaluation of the influenza vaccine effectiveness among children aged 6 to 72 months based on the test-negative case control study design. Zhonghua Yu Fang Yi Xue Za Zhi 2019; 53(6): 576-80.

20. Tanriover MD, Bagci Bosi T, Ozisik L, Bilgin E, Güzel Tunçcan Ö, Özgen Ö, et al. Poor outcomes among elderly patients hospitalized for influenza-like illness. Curr Med Res Opin 2018; 34(7): 1201-7. 